\title{
SHAPING THE CREDIT RISK MANAGEMENT OF BANKS
}

\author{
Vladan Kovacevic $^{1}$
}

\begin{abstract}
The increasing importance of credit risk management in the bankingsector is the subject of research presented in this paper. Research goals include determining the importance and influence of risks on business success of banks in strategic terms, in the long run. In this sense, key results of empirical research on the territory of Serbia in 2015 on a sample of 34 financial institutions, (69 percent of the total number of banks in Serbia), have been provided. The results which were processed by theoretical, statistical and mathematical methods confirmed validity of the proposed hypothesis that risks have a great impact on revenues of companies. The significance of research results can be seen in the implementation of theory and practice, as well as the tools for assessing internal and external risks which might influence banking operations and sustainability. Kljucne reči: obrazovanje / radni staž / predskolske ustanove / zaposleni / zadovoljstvo.
\end{abstract}

Key words: banks / risk management / internal and external risks / bank revenues / risk assessment tools

Jel classification: G21; G28; G31

\section{Introduction}

The existing business environment is highly risky, especially in the financial sector, thus it requires the appropriate actions to reduce the risks. Banking activity is exposed to various risks. Achieving profitability in the environment of increased competition and growth of risk becomes a challenge for modern banking management, as well as for insurance and IT industry, which are all connected by stronger protection models in that field (Jevtic \& Vucekovic, 2014, p. 27).

\footnotetext{
${ }^{1}$ MA, doctoral studies, Faculty of Economics and Engineering Management, University Business Academy, Novi Sad, Serbia
} 
According to Aleksey (Aleksey, et al., 2014: 9-18), smaller banks in Europe have increased their long-term assets by 14 percent during the past seven years (from $17 \%$ in 2006 to $31 \%$ in 2013 ).

McKinsey Institute in its current study about the future of bank risk management (Harle, et al., 2015, pp. 1-32) writes about substantially changed risk management in banks over the past ten years. The study sees the reasons for it in the novel regulations concerning more demanding capital and funding requirements, leverage and liquidity. The proposed higher standards include: risk reporting in banks which has to follow new requirements regarding higher standards, tightened standards for compliance, as well as non-financial risks.

Some new tools, such as stress test, are implemented more often. The expectations are that the bank risk appetite will rise.

There are other trends in bank risk management regarding definition of the lines of defense:

- Strengthening risk culture in banking;

- Close involvement of boards in key risk decisions;

- Implementation of broader risk management policy requirements.

As far as the Serbian banking system is concerned, it suffers since the time of sanctions and has been under the growing influence of international environment, so the impact of risks on the stability of financial system has been rapidly increasing. According to the data of the National Bank of Serbia for 2015, the banking sector in Serbia operated through the organizational network of 1,765 business units, with 24,753 employees.

Changing perceptions of the risk of placing funds, primarily of Serbian companies, may prove to be the key factor of growth of loan activity of banking sector. In this respect, it should be noted that stopping the further growth of NPLs (non-performing loans) and solving their current level will be a precondition for further loan growth. Understanding and quantifying these risks is crucial for bank management (Sieczka, Holyst, 2009: 461-466).

This paper is based on theoretical and empirical research of the risk management issues, protection models in Serbia and the data gathered and analyzed in 2015. A sample of 113 production and service enterprises and institutions was involved in 
the field research. In the sample of financial institutions we included $69 \%$ of the banks operating in Serbia. For the purpose of writing this paper, authors selected one of the main banking risks, namely-credit risk, and the paper presents some of the key findings of the research.

\section{Literature Review}

Credit risk is the most important factor in determining lending practices, (Daniels, Ramirez, 2008, pp. 35-59). Credit risk is of great importance for all areas of recent financial research, so Duff and Eying (2009, pp.107-119) analyzed the meaning, role, and influence of credit ratings. According to the National Bank of Serbia and in accordance with Basel principles, credit risk or default risk involves a customer's inability and unwillingness to meet the commitments in relation to the trading, hedging, settlement, and other financial transactions in connection with lending. The measurement of credit risk is a crucial activity in credit risk management. Davies and Kearns (1992) emphasize the need of banks to apply certain procedures for measuring their exposure to credit risk, as well as their exposure to the connected parties, products, customers and economic sectors. Different types of financial risk/credit risk could be depicted in the following manner:

Figure 1. Credit risk

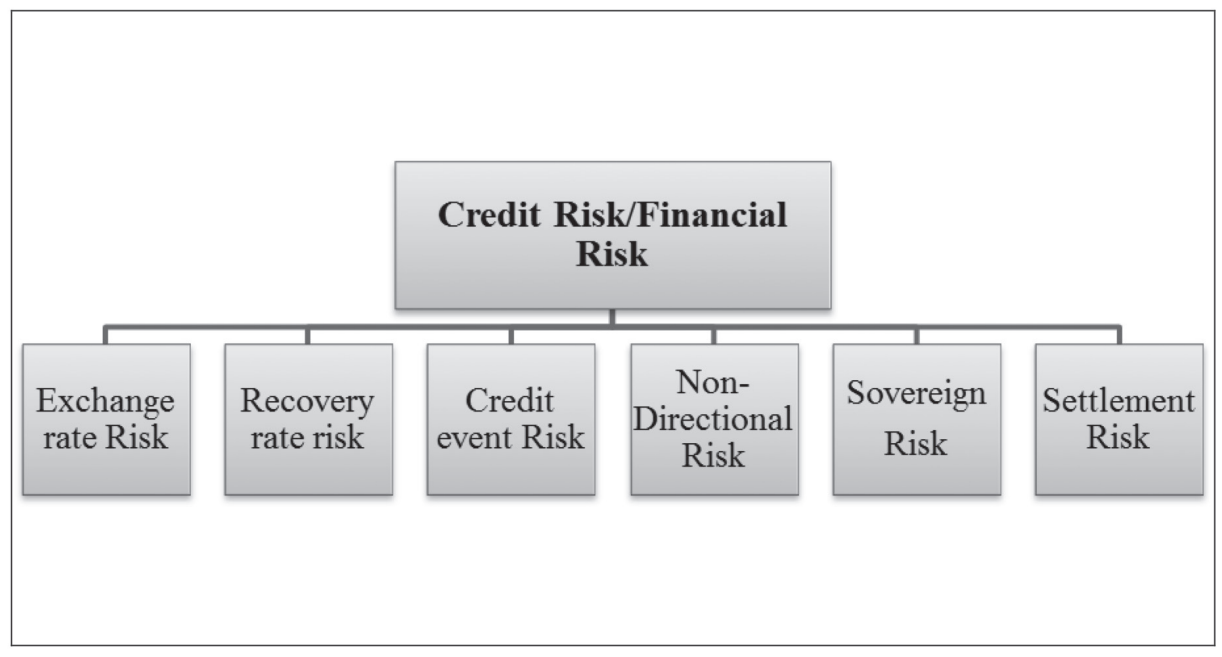

Source: Origin of financial risk according to Kungwani (Kungwani, 2014, p. 85) According to Miller (2008), credit risk management could the defined as a decision making process before the credit decision is made, and the follow-up of credit 
agreements, as well as monitoring and reporting processes. Government intervention can cause bank distress, according to Kane and Rice (1998, pp. 1-49). Politically directed lending leads to the bank failures as dishonest and greedy leaders exploit the funds of banks. Bank failures arise because banks avoid keeping the deposits according to the statutory regulations on reserve funds (Njanike, 2009, pp.173-184).

\section{Methods and Materials}

\subsection{Sampling}

For the purpose of this research, we analyzed risk management in Serbian companies in 2015. The sample contained 27 percent of banks (out of the total number of 39 banks in Serbia this makes 69 percent, which makes the results of the research very representative). An interview/questionnaire consisted of 33 open and closed type questions regarding the awareness of companies of various risk impacts, increasing normative and capital requirements, and their practices in modeling, risk reporting, organizing and executing different risk management phases within the organization. For the purpose of this paper, the most interesting findings concerning internal credit risk are presented.

\subsection{Methodology}

The analysis of obtained results is based on empirical research, statistical analysis of the degree of impact of risk management on performances of companies and banks, as well as the implementation of the new risk management protection models.

Theoretically, the used statistical methods could be divided as:

- Basic methods of descriptive statistical analysis of the observed data.

It primarily refers to the calculation of frequencies of individual answers of the respondents: absolute and relative (percentage). Based on them, for the numerical characteristics of the survey it is possible to determine the key statistical parameters, mean value and standard deviation for the hypothesis proposed, i.e. survey question within the survey, which is precisely what was done;

- Statistical testing of dependences between individual variables of the sample, where Pearson's $\chi^{2}$ (Chi-Square) (Pearson, 1900, pp. 59-72) test of independence was used for certain characteristics of the given sample. 
In the analysis and interpretation of research results in this paper, $\chi^{2}$ test was first used in the statistical analysis of the structure of the sample. The basic measuring unit in statistical analysis is individually interviewed company's/bank's independence test on the basis of positive answers to the appropriate survey questions, and the total number of positive values of the observed variables.

For this purpose the so-called "zero" or initial hypothesis $(\mathrm{H} 0)$ of independence of the observed characteristics was introduced, i.e. it assumes that values of the observed variables do not depend on the basic activity of a particular company/bank.

If the anticipated frequencies are marked with $f \square$ and empirical frequencies are marked with $f$, , the total number of positive responses for each of the variables as the realized value - the so-called $\chi^{2}$ statistics, could be calculated by the following formula:

$$
\chi^{2}=\sum_{i=1}^{r} \frac{\left(f_{i}-f_{i}\right)^{2}}{f_{i}} \text {, }
$$

Here, $f$ and $f$ ' are empirical and expected frequencies, and $\mathrm{r}$ is the number of different modalities (number of variables, i.e. survey questions).

Multiple regression analysis was used for formal verification of the hypothesis. These models are called linear regression models and the main assumption for their application is that among the observed events there is a linear (straight line) connection that will be best expressed by an equation.

In modern statistics, in a variety of situations, complex regression models are most commonly used, such as logistic regression, which is a special type of regression analysis with the aim to predict the outcome of the so-called binary (dichotomous) random variables. This way, logistic regression is often used in a number of applied disciplines: medical and social sciences (Jaccard, 2001, pp. 46-50), in processing of surveys, market research forecasting consumer preferences towards the purchase of the product, to describe different aspects of business and enterprise development (Karlsson et al., 2012, pp. 1-27). It is commonly used in similar situations, when dependent and/or independent variables (answers to survey questi- 
ons) are dichotomous, i.e. in the examples similar to the ones in this paper, with only two values: 0,1 .

\subsection{Key results}

The hypothesis of the research is defined as:

- $\mathrm{H} 1=$ credit risk management has a positive impact on a bank's performances. Banks in Serbia, apart from the credit risk in their risk management practices, assessed further types of risks:

- Risk of financial reporting;

- Liquidity risk;

- Equity and funding risk;

- Operational risk;

- Human resources risk;

- Strategic risk; and

- Reputational risk.

If each of these risks is treated as a variable with an important impact on banking business and revenues, the attitude scale enables determination of coefficients of logistic regression. Statistical analysis of the specific impact of various sources or categories of credit risk in the surveyed banks is presented below. The distribution of the number of positive responses, their proportions and the corresponding standard deviations are given in Table 1.

It is obvious that the majority of surveyed banks see the risk of an individual client as a special type of credit risk, as well as the whole portfolio and the average loan size.

Table 1 shows a great positive impact and positive correlation of these variables with the amount of total income of banks. 
Table 1. Types of risks that banks measure (attitude scale)

\begin{tabular}{|l|c|c|}
\hline Variables & Types of risk & Attitude scale \\
\hline Regression constant & \multicolumn{2}{|c|}{} \\
\hline$X_{2}$ & Strategic risk & 0.3077 \\
\hline$X_{3}$ & Risk of financial reporting & 1.1250 \\
\hline$X_{4}$ & Management risk & 1.0000 \\
\hline$X_{5}$ & Reputational risk & 1.1250 \\
\hline$X_{6}$ & Human resources risk & 1.2667 \\
\hline$X_{7}$ & Operational risk & 0.8889 \\
\hline$X_{8}$ & Liquidity risk & 1.2667 \\
\hline$X_{9}$ & Credit risk & $\mathbf{0 . 4 1 6 7}$ \\
\hline$X_{10}$ & Equity and funding risk & 1.1250 \\
\hline$X_{11}$ & Other & 0.4167 \\
\hline Total error $(Q):$ & 0.2671 & \\
\hline $\begin{array}{l}\text { Coefficient of } \\
\text { determination }(R 2):\end{array}$ & 0.8751 & \\
\cline { 1 - 2 } AIC: & 35.431 & \\
\hline
\end{tabular}

Source: Author's calculations

Notice: The table is designed in Word program

The above statistical analysis shows that different types of internal risks have different impacts on operations of the surveyed banks. The risk of capital and financing has the highest impact on businesses; it is followed by the coefficients of operational risk, as well as the risk of human resources.

Banks principally take care of the following elements of credit risk:

- Capital adequacy;

- Capitals size;

- Problems in obtaining loans; and

- Conditions to be fulfilled for lending. 
The level of importance of measuring each element of banking credit risk is presented in Figure 1.

Figure 1. Elements of banking credit risk

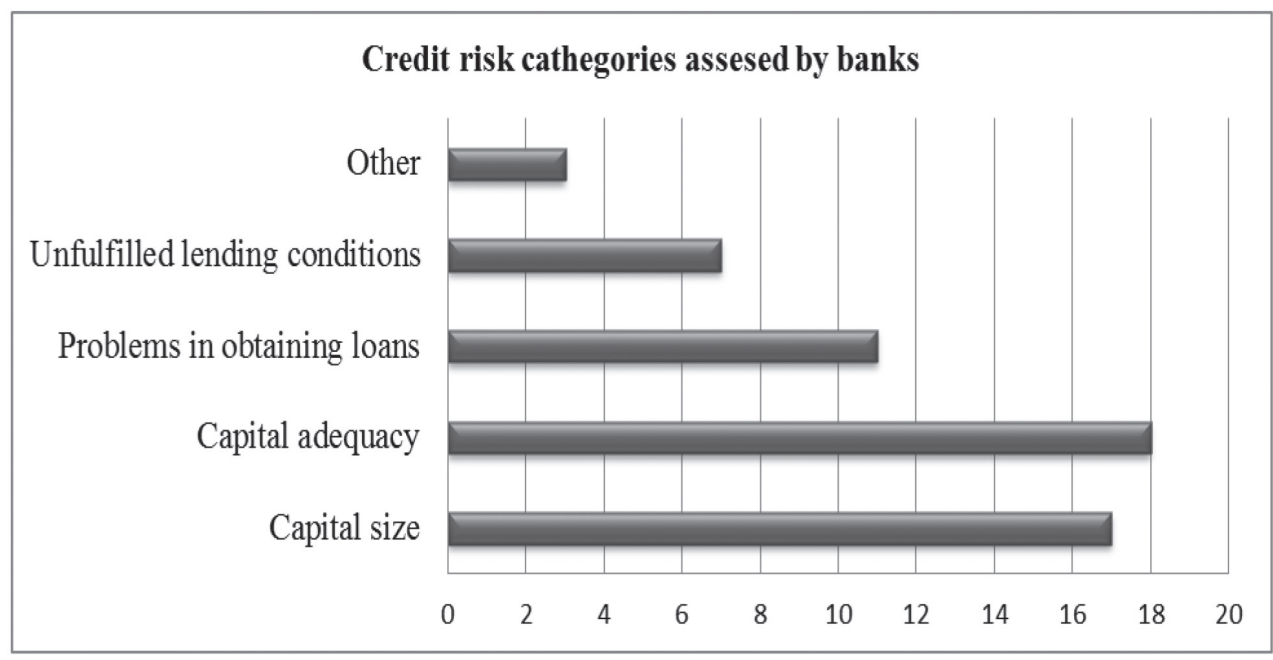

Source: Author's calculations

The entire statistical analysis was based on application of the relevant theoretical facts and modern trends in theoretical and statistical analysis of the related problems and it confirms the validity of hypothesis.

Banks in Serbia measure the following data regarding credit risk (Figure 2):

- Average loan size (most banks put this in the first place and even change their scope of business lending to micro and small companies depending on the level of risk);

- Whole credit portfolio;

- Individual clients;

- Groups of related parties;

- Lending to companies and clients from specific economy sectors; 
- Creditworthiness;

- Lending to clients in a defined geographical area (e.g. South Serbia or some rural areas).

Credit risk management takes care of risk groups, special reserves and other categories too.

Figure 2. Credit risks categories

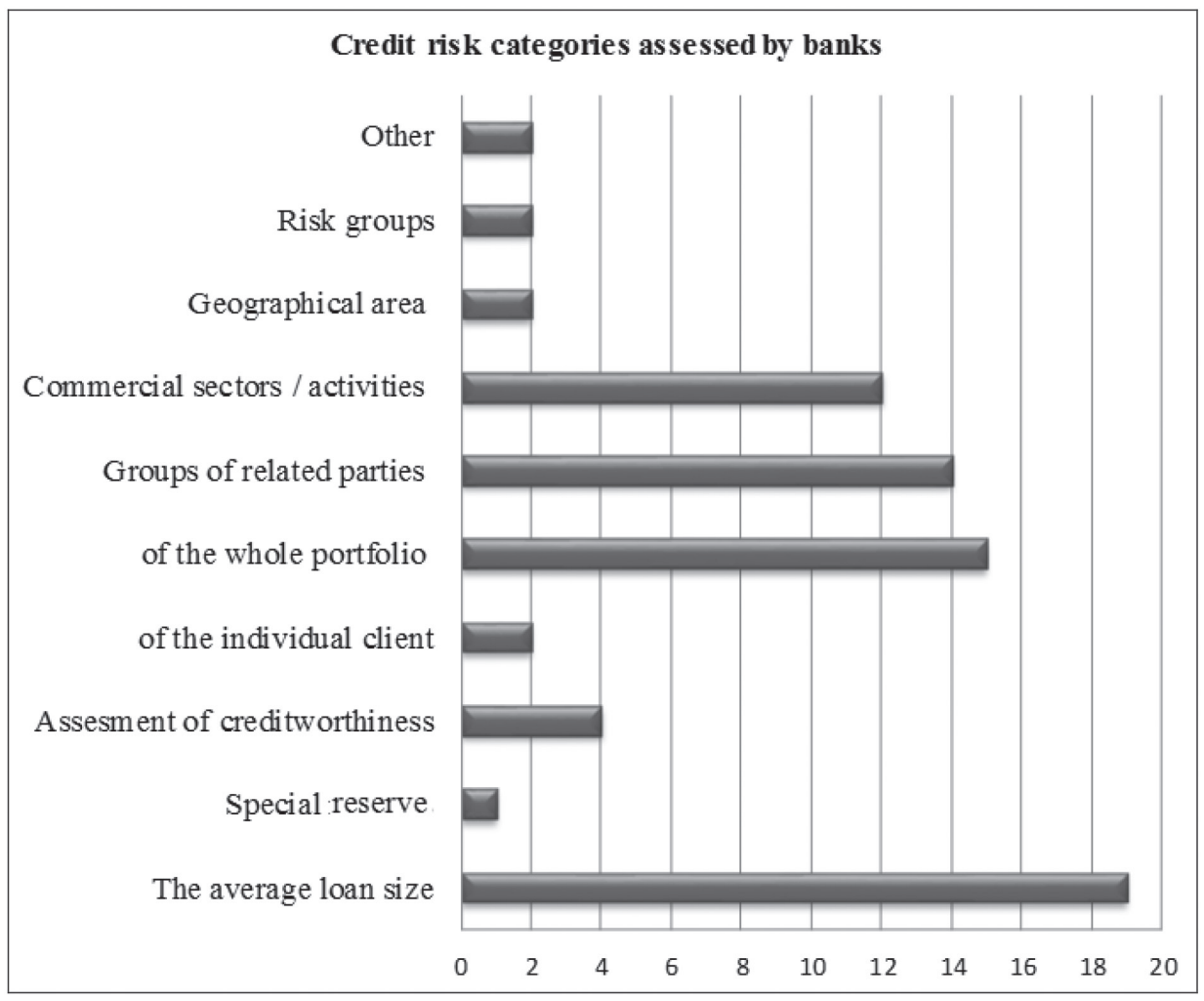

Source: Author's calculations

\section{Discussion}

Formal verification of the proposed hypothesis was done by applying the statistical methods of descriptive statistics and analysis, Pearson test of independence, a model of multiple regression analysis, linear regression model, logistic regression and 
programming languages appropriate for the research results. The realized ratios, legit function and the estimated value of logistic regression coefficient of the entire sample surveyed indicate that the obtained logistic regression is an adequate theoretical model for interpretation and dynamic analysis of the observed empirical data.

The relatively small value of AIC coefficient (42.281) confirms conclusions that the choice of this theoretical model objectively and adequately interprets the dichotomous structure of the observed empirical data, and it can confirm validity of the Hypothesis $\mathrm{H} 1$ that credit risk management has a positive influence on income and bank's performances.

\section{Conclusions}

This paper intended to provide answers to the following questions: What kind of internal and external risks do companies and banks in Serbia measure separately, and what is the importance of credit risk; Which elements do banks analyze in their credit risk assessment; How does this impact income and revenue of banks?

The research confirmed that: credit risk management issue is perceived as a discipline of growing importance in operations of companies and banks, and so are the elements which make up such an important aspect of permanent impact on sustainability (Njanike, et al., and 2009: 173-184) and capacities of a business.

The methodology used for this research, namely, questionnaire and interviews for collecting the data, as well as statistical and mathematical methods were adequate and helpful for an objective research. The data for this research was collected from directors, consultants and bank managers based in Serbia. The research results are of great importance for further practice development and implementation of scientific tools in credit risk measurement in banks since Serbia has a very high rate of non-performing loans, more than 30 percent, which is the highest rate in the region.

The National Bank introduced new legislation for banks for the purpose of decreasing these loans. These activities together with the introduction of the new risk metrics, changes in business models and high competitive pressure within the industry could help banking sustainability in the long run. 


\title{
UOBLIČAVANJE UPRAVLJANJA RIZIKOM U BANKAMA
}

\author{
Vladan Kovačević
}

Sažetak: Predmet istraživanja predstavljen u ovom radu jeste rastući značaj upravljanja kreditnim rizikom u bankarskom sektoru. Ciljevi istraživanja obubvataju utvrdivanje značaja i uticaja rizika na uspešnost poslovanja banaka u strateškom smislu na dugi rok. U tom cilju su prezentovani osnovni rezultati empirijskog istraživanja sprovedenog u Srbiji, 2015. godine, na uzorku od 34 finansijske institucije (69 odsto ukupnog broja banaka u Srbiji). Rezultati su obradeni teorijskim, statistickim i matematickim metodama kojima se potvrduje ispravnost definisane hipoteze, da ovi rizici značajno uticu na prihode firmki. Doprinos rezultata istraživanja se vidi u primeni teorijskih $i$ empirijskih znanja $i$ alata za procenu unutrašnjib $i$ spoljnih rizika koji mogu da uticu na bankarske operacije i održivost.

Ključne reči: banke / upravljanje rizikom / unutrašnji i spoljni rizici / prihodi banaka / alati procene rizika

JEL klasifikacija: G21; G28; G31

\section{REFERENCES}

1. Aleksey, V., Jerkovic, S., Ilic, S. (2014). The first US intervention in Serbian economic reconstruction, International Review, No.3-4, 9-18.

2. Daniels, K., Ramirez, G. G. (2008). Information, credit risk, lender specialization and loan pricing: evidence from the DIP financing market, Journal of Financial Services Research, 34(1), 35-59.

3. Davies, A., Kearns, M. (1992). Banking operations: U. K. lending and international business, Pitman

4. Duff, A., Eying, S. (2009). Understanding credit ratings quality: evidence from UK debt market participants, The British Accounting Review, 41(2), 107-119.

5. Harle, P., Havas, A., Kremer, A., Rona, D., Samandari, H. (2015). The future of bank risk management, McKinsey, 1- 32.

6. Jaccard. J. (2001). Interaction effects in logistic regression, SAGE Publications, Issue 135, pp. 46-50, Thousand Oaks, CA.

7. Jevtic, B., Vucekovic, M. (2014). Technological Innovations, evidence from Serbia, International review, Vol. 3-4/2014 
8. Kane, E.J., Rice, T. (1998). Bank runs and banking policies: lessons for African policymakers, pp.1-49, Revised Draft, available at: http://citeseerx.ist.psu. edu/viewdoc/download? doi=10.1.1.196.7362 \&rep=rep1\&type=pdf

9. Karlsson, C., Johansson, B., Stough, R. (2012). Entrepreneurship, social capital and governance, Edward Elgar, Northampton, USA, pp.1-27

10. Kungwani, P. (2014). Risk management - an analytical study, IOSR Journal of Business and Management (IOSR-JBM) Volume 16, Issue 3. Ver. III (Feb. 2014), pp. 83-89, available at: www.iosrjournals.org.

11. Miller, S. (2008). The importance of credit risk management for banking, on line article, downloaded from: http://ezinearticles.com/?The-Importanceof-Credit-Risk-Management-for-Banking\&id=1102802

12. Njanike, K. (2009). The impact of effective credit risk management on bank survival, Annals of the University of Petroşani, Economics, Vol. IX - part II, Universitas Publishing House Petroşani - Romania, pp.173-184, available at: http://www.upet.ro/anale/economie/

13. Pearson, K. (1900). Chi-squared test, International Statistical Review, 51 (1983), pp. 59 -72. Longman Group Limited/Printed in Great Britain

14. Sieczka, P., Holyst, J. A. (2009). Collective firm bankruptcies and phase transition in rating dynamics. The European Physical Journal B - Condensed Matter and Complex Systems, 71(4), pp. 461-466 